\title{
DIVIDED WE STAND \\ Institutional Sources of Ethnofederal \\ State Survival and Collapse
}

\author{
By HENRY E. HALE*
}

$\mathrm{D}^{\mathrm{os}}$ OES ethnofederalism, a federal political system in which component territorial governance units are intentionally associated with specific ethnic categories, tend to promote state survival or collapse? This question is critical, since many of the world's largest and most important states - including India, China, Russia, and Canada- have at least nascent ethnofederal structures. Moreover, ethnofederalism is frequently recommended for countries torn by ethnic conflict and, indeed, has been proposed as the foundation for efforts to rebuild both postTaliban Afghanistan and post-Saddam Iraq. ${ }^{1}$

Recent scholarship tends to point in contradictory directions. Many researchers have attributed the dramatic collapses of the USSR, Yugoslavia, and Czechoslovakia at least in part to ethnofederalism. ${ }^{2}$ Others have argued that ethnofederal arrangements generally do not work well in Africa while "segmental federalism" has been blamed for

*The author is indebted to Ryota Dei, Brent Never, and Naomi Wachs for energetic research assistance and to many others who provided helpful feedback and support, including Andrew Buck, Edward Gibson, Yoshiko Herrera, Pauline Jones Luong, Daniel Posner, Jack Snyder, Ashutosh Varshney, Steven Wilkinson, the anonymous reviewers of earlier drafts, and participants in a workshop of the Program on New Approaches to Russian Security held in Seattle, 2002. The author also gratefully acknowledges the encouragement of the committee for the Combating Political Violence paper competition sponsored by the Institute of War and Peace Studies at Columbia University, which selected an earlier version as a winning paper.

${ }^{1}$ Kanan Makiya, presentation at the American Enterprise Institute, reported in Washington File, October 8, 2002 (http://usinfo.state.gov/products/washfile); Michael Rubin, "What Do Iraqis Think about Life after Hussein?" New York Times, August 11, 2002; Nazif Shahrani, "Afghanistan Can Learn from Its Past," New York Times, October 14, 2001, sec. 4, 13; Peter Slevin, "Undefined U.S. Plans for Post-Hussein Iraq Stir Questions," Washington Post, October 10, 2002 , A18.

${ }^{2}$ Rogers Brubaker, Nationalism Reframed (New York: Cambridge University Press, 1996); Valerie Bunce, Subversive Institutions (NewYork: Cambridge University Press, 1999); Beverly Crawford, "Explaining Cultural Conflict in Ex-Yugoslavia," in Crawford and Ronnie D. Lipschutz, eds., The Myth of Ethnic Conflict, International and Area Studies Research Series, no. 98 (Berkeley: University of California, Berkeley, 1998); Gail W. Lapidus, "From Democratization to Disintegration," in Lapidus and Victor Zaslavsky, with Philip Goldman, eds., From Union to Commonwealth (NewYork: Cambridge University Press, 1992); Carol Skalnik Leff, "Democratization and Disintegration in Multinational States: The Breakup of the Communist Federations," World Politics 51 (January 1999); Philip G. Roeder, "Soviet Federalism and Ethnic Mobilization," World Politics 43 (January 1991); idem, "Peoples

World Politics 56 (January 2004), 165-93 
Canada's flirtation with breakup. ${ }^{3}$ This institutional arrangement, they concur, has had the effect of strengthening ethnic difference and providing resources for political entrepreneurs to play the "nationality card," thereby promoting secessionist activity. ${ }^{4}$ Others, typically citing cases like India and Switzerland, have argued that ethnofederalism can help preserve ethnically divided states by satisfying demands for autonomy on key issues, localizing potential conflicts, promoting unifying identities, and reducing opportunities for the central government to exploit minority regions. ${ }^{5}$ While some theorists have ventured hypotheses to explain part of this variation, these remain tentative first steps. ${ }^{6}$ Even William Riker's seminal work on federalism does not take a stand on this question despite noting some of the issues involved. ${ }^{7}$

This article brings these studies together by elaborating an institutional logic that underpins the findings they identify. Specifically, ethnofederal states are more likely to collapse when they contain a core ethnic region - a single ethnic federal region that enjoys dramatic superiority in population. Such regions tend (1) to promote the rise of "dual power" situations that are frequently at the heart of state breakdown and revolution; (2) to reduce the capacity of central governments to credibly commit to the security of ethnic minority regions, and; (3) to facilitate the collective imagining of a core-group nation-state separate from the union state. Conversely, in ethnofederal countries where one

and States after 1989," Slavic Review 58 (Winter 1999); Yuri Slezkine, "How a Socialist State Promoted Ethnic Particularism," Slavic Review 53 (Summer 1994); Anthony D. Smith, "Ethnic Identity and Territorial Nationalism in Comparative Perspective," in Alexander J. Motyl, ed., Thinking Theoretically about Soviet Nationalities (New York: Columbia, 1992); Ronald Grigor Suny, The Revenge of the Past (Stanford, Calif.: Stanford University Press, 1993).

${ }^{3}$ On Africa, see Shaheen Mozaffar and James R. Scarritt, "Why Territorial Autonomy Is Not a Viable Option for Managing Ethnic Conflict in African Plural Societies," Nationalism and Ethnic Politics 5 (Autumn-Winter 1999); and Augustine Wamala, "Federalism for Africa," in Bertus De Villiers, ed., Evaluating Federal Systems (Boston: Martinus Nijhoff, 1994). On Canada, see Hudson Meadwell, "Breaking the Mould?" in Sukumar Periwal, ed., Notions of Nationalism (Budapest: Central European University Press, 1995).

${ }^{4}$ Jack Snyder, From Voting to Violence (New York: W. W. Norton, 2000).

${ }^{5}$ Nancy Bermeo, "The Import of Institutions," Journal of Democracy 13 (April 2002), 96-110; Paul R. Brass, "Language and National Identity in the Soviet Union and India," in Motyl (fn. 2); Ted Robert Gurr, Minorities at Risk (Washington, D.C.: U.S. Institute of Peace, 1993), 300-301; Atul Kohli, "Can Democracies Accommodate Ethnic Nationalism?" Journal of Asian Studies 56 (May 1997); Arend Lijphart, Democracy in Plural Societies (New Haven: Yale University Press, 1977); Graham Smith, ed., Federalism: The Multiethnic Challenge (New York: Longman, 1995), 3.

${ }^{6}$ Bunce (fn. 2); Michael Hechter, Containing Nationalism (New York: Oxford University Press, 2000), 140, 149-58; Donald L. Horowitz, Ethnic Groups in Confict (Berkeley: University of California Press, 1985), 601-28; Rita Jalali and Seymour Martin Lipset, "Racial and Ethnic Conflicts," Political Science Quarterly 107 (Winter 1992-93), 601; Kohli (fn. 5); Leff (fn. 2); Juan J. Linz and Alfred Stepan, "Political Identities and Electoral Sequences," Daedalus 121 (Spring 1992); Alfred Stepan, "Federalism and Democracy: Beyond the U.S. Model," Journal of Democracy 10 (October 1999), 19-34; Ronald L. Watts, "Contemporary Views on Federalism," in De Villiers (fn. 3), 10-12.

${ }^{7}$ Riker, Federalism: Origin, Operation, Significance (Boston: Little, Brown, 1964). 
group dominates in population but where that group is divided up into a number of distinct federal regions rather than united in one core ethnic region, the dominant group faces major obstacles to collective action that inhibit it from creating the most serious dual-power situations, that reduce the threats perceived by minority ethnic regions, and that hinder the efforts of political entrepreneurs to promote the collective imagining of an independent core nation-state. So long, therefore, as ethnofederalism is instituted without a core ethnic region, it presents a viable alternative to partition as a way of avoiding the most deadly forms of conflict in ethnically divided countries.

This article begins by defining key concepts and proceeds to elaborate the theoretical logic. It breaks down the notion of state collapse into two categories, state breakup and large-scale civil war, and distinguishes these from individual secessions and other smaller-scale problems facing states. The theory is then tested in two ways. The article first examines broad patterns evident in all of the world's major ethnofederal states that have existed since World War II. Strikingly, it is found that all ethnofederations that have collapsed have possessed core ethnic regions, whereas no ethnofederation lacking a core ethnic region has collapsed. Second, the article turns to a more detailed examination of two key cases, Nigeria and the USSR/Russia, each of which experienced ethnofederalism both with and without core ethnic regions. These case studies demonstrate that the institutional logic of core ethnic regions was in fact the key causal factor distinguishing the instances of state collapse and state survival in these countries. Thus, the theory. accounts not only for broad patterns but also for how the patterns obtained in individual states.

\section{KEY CONCEPTS}

\section{ETHNOFEDERALISM}

An ethnofederal state is a federal state in which at least one constituent territorial governance unit is intentionally associated with a specific ethnic category. ${ }^{8} \mathrm{~A}$ federal state is any state with both of the following two elements. First, it must have a federal constitution, as specified by Riker to be "federal if (1) two levels of government rule the same land and people; (2) each level has at least one area of action in which it is autonomous; and (3) there is some guarantee (even though merely a

\footnotetext{
${ }^{8}$ Roeder (fn. 2, 1991). In what follows, the terms "ethnofederalism" and "ethnofederal system" refer to the set of institutions that make a state an ethnofederal state and the term "ethnofederation" denotes an ethnofederal state. "Ethnofederal regime" refers to the central government of an ethnofederal state.
} 
statement in the constitution) of the autonomy of each government in its own sphere." And second, it must have at least the minimum level of democracy needed, such that the concept of regional autonomy has some meaning, including some kind of direct popular election to state organs of the highest level of territorial governance unit underneath nationwide state organs. This definition, therefore, clearly includes cases like India and Canada and excludes countries like Australia (a federation that is not based on ethnic divides) and Romania (a multiethnic but unitary state). It also excludes cases like Uganda, in which a decentralizing reform did not institute direct elections for its forty-five districts but instead chose to directly elect village committees, which then were to elect parish committees, which then were to elect subcounty committees, and so on through the county and ultimately district levels. ${ }^{10}$

Operationally, countries are considered to possess the necessary "minimum level of democracy" if they hold direct regional elections and if Freedom House rates these countries as either "free" or "partially free." 11 This clearly disqualifies countries such as China, whose constitution nominally grants autonomy to certain regions designated for particular ethnic minorities (such as the Uighurs in Xinjiang) but which has no significant electoral democracy at the level of these ethnic regions. Cases like China may be called latent or nascent ethnofederations but not actual ethnofederations. Under this conceptualization, the USSR was only a latent ethnofederation until it started to liberalize and grant its provinces (republics) some real autonomy; therefore, the USSR actually became ethnofederal only with the regional elections of 1990 , whereupon it was first coded as "partially free" by Freedom House.

\section{Full Ethnofederations VERSUS PARTIAL ETHNOFEDERATIONS (AUTONOMY ARRANGEMENTS)}

One set of cases that deserves special mention here includes otherwise unitary countries that have devolved some local power to particular ethnic regions as part of an ethnic autonomy arrangement. Examples include Nicaragua's agreement with the Miskito Indians, Indonesia's arrangements with Aceh and Jogyakarta, and Sudan's devolution of

\footnotetext{
${ }^{9}$ Riker (fn. 7), 11.

${ }^{10}$ Nelson Kasfir, "Uganda," Microsoft Encarta Online Encyclopedia 2002 (http://encarta.msn.com).

${ }^{11}$ These ratings (available at www.freedomhouse.org) cover 1972-2003. For cases not covered by Freedom House ratings, judgment was based on expert accounts (in such instances, judgments about temporary shifts away from democracy are not reported in Figure 1, for simplicity's sake, as these do not matter for the overall findings). Since the general conclusions of this study are confirmed regardless of whether any borderline-democracy cases are excluded or included, the presumption is to include them so readers can see for themselves that their inclusion or exclusion makes no difference to the overall empirical findings and argument.
} 
power to its "South" during 1972-83. A similar case is the 1948-62 Burma Union. Its core region, often referred to as "Burma proper," had no government and legislature of its own and was administered directly by the Union government and legislature; only Burma's ethnically defined "states" had formal autonomy. In such instances, the three parts of Riker's definition of federalism given above (including that "two levels of government rule the same land and people") apply only to the ethnic region that is granted autonomy, not to the rest of the country. In an important sense, then, such states are partially ethnofederal. ${ }^{12}$

There is good reason to treat partial ethnofederalism and full ethnofederalism as having distinct effects on the propensity for state collapse. For one thing, the elimination of autonomous regional governments representing some territories can be expected to change the nature of center-regional bargaining, to alter how the central government formulates its relationship to the nonautonomous regions in comparison with other regions, and to shift how the autonomous minority regions perceive that relationship. Furthermore, the sharp distinction between how autonomous and "regular" territories are governed in partial ethnofederations can be expected to produce different dynamics than in full ethnofederations, where the state is founded on a principle of universal regional autonomy. The present article is concerned primarily with full ethnofederations, leaving an examination of patterns in partial ethnofederations for consideration elsewhere. ${ }^{13}$

\section{CORE ETHNIC REGION}

An ethnofederal region is a core ethnic region if it contains either an outright majority of the population or makes up at least 20 percent more of the whole country's population than does the second largest region. While the number of 20 percent is, of course, somewhat arbitrary, it is a good indicator of a point beyond which one group is likely to be considered "clearly" dominant in terms relevant to the logic of the theory and thus suffices for the purposes of operationalizing the theory. ${ }^{14}$ This relative (population) size requirement applies to the ter-

\footnotetext{
${ }^{12}$ On Sudan, see Nelson Kasfir, "Southern Sudanese Politics since the Addis Ababa Agreement," African Affairs 76 (April 1977); and Timothy C. Niblock, "A New Political System in Sudan," African Affairs 73 (October 1974). On Burma, see the Constitution of the Union of Burma, 1948 (www.shanland .org, accessed January 19, 2004); and Josef Silverstein, “The Federal Dilemma in Burma," Far Eastern Survey 28 (July 1959).

${ }^{13}$ For one study of partial ethnofederations, see Svante E. Cornell, "Autonomy as a Source of Conflict: Caucasian Conflicts in Theoretical Perspective," World Politics 54 (January 2002).

${ }^{14}$ In general, while we cannot assume a perfectly linear relationship, one should expect to see the dynamics of the present theory at work more clearly the greater the gap between the largest and second-largest regions.
} 
ritorial administrative unit (that is, the region) rather than to the ethnic group. This is because, as the theory conceives it, the destabilizing dynamics primarily have to do with the institution rather than the group, as will become clear below. The category of core ethnic region thus fits, for example, the following cases: the USSR's giant Russian Republic (RSFSR), which contained a majority of the Soviet population and whose dominant nationality (Russian) was also the majority group in the country; the Nigerian First Republic's Northern region, which included a majority of the country's population and was dominated by the Hausa-Fulani group even though this group was not an actual majority nationwide (though it did constitute a plurality); and the former Yugoslavia's Serb Republic, which constituted 42 percent of the country's population as against the 20 percent of the population made up by Croatia, the second-largest republic. ${ }^{15}$

\section{ETHNOfEDERAL STATE COllaPse}

Many problems can befall states but not all of these problems constitute state collapse. In using the term state collapse, one hopes to capture the occurrence of extreme events, specifically those instances when central state institutions effectively lose their ability to provide even the most modest degree of order over the bulk of their territory. More specifically, in talking about the actual collapse of ethnofederations, we have in mind two such extreme events.

First is the notion of state breakup: an ethnofederal state "collapses" when it fragments along more than half of its ethnofederal lines. We can operationalize this by noting whether the central government of a given country loses control of over half of its constituent ethnic minority units for a period of a year or more. Collapse is thus something more momentous than simple secession, which can happen in isolated instances without threatening central government control over the rest of its territory. The successful secession of a single ethnic region does not constitute ethnofederal state collapse unless it is part of a wave of multiple successful secessions from the same country or unless it is the only ethnic minority region in that country. Thus, we typically say that the USSR collapsed because the Gorbachev government faced multiple secessions that effectively undermined its authority across the rest of the country. We did not say, however, that "Russia collapsed" when Chechnya successfully defended its de facto independence in a war with Russia during 1994-96.

\footnotetext{
${ }^{15}$ Dennison Rusinow, "Yugoslavia," Microsoft Encarta Online Encyclopedia 2002 (http://encarta .msn.com).
} 
A second extreme event falling under the category of state collapse is large-scale civil war. Here we have in mind the kind of systematic and sustained domestic violence that results in the effective suspension or elimination of regular government institutions throughout the whole country (typically involving the institution of dictatorship), regardless of who wins. Operationally, to qualify as state collapse, we require that such a civil war (1) involve the suspension of regular government institutions and (2) endure for at least one year. Both of these things are empirically identifiable and clearly distinguish polities that have effectively lost control of their countries (the cases of greatest interest to us in this article) from those that might face isolated or tightly geographically contained emergencies that the state is equipped to manage. Thus, for example, looking at sustained but contained rebel activity in Assam or periodic communal violence in Gujarat, we do not say that India has collapsed. This is because neither set of violent episodes, despite spanning more than a year, has involved the effective suspension of regular Indian government institutions across the entire country. One can say, however, that Nigeria (its First Republic) collapsed for the period of the Biafran civil war and that Pakistan collapsed during 1971-72, when a newly ethnofederal regime was abandoned and the ensuing civil war killed hundreds of thousands ${ }^{16} \mathrm{~A}$ peaceful decision to turn an ethnofederal state into a unitary one is also not "state collapse" unless this decision is somehow forced on the central government through civil war. Thus, unlike 1971-72, Pakistan did not "collapse" in 1999, when Musharraf suspended democratic government.

In seeking to explain why some ethnofederal states have collapsed but others have not, this article attempts to account for why some countries have suffered the most extreme forms of breakdown with the greatest consequences both for their own citizens and for the international community. ${ }^{17}$ We thus leave for future work the determinants of

\footnotetext{
${ }^{10}$ India ultimately intervened after the bloody civil war had ground on for close to nine months, producing a quick surrender by the unionist Pakistani army and securing independence for Bangladesh. Violence related to this war, mostly involving unionist groups that had fought with the Pakistani army in Bangladesh, continued sporadically for over three more months after the formal Pakistani surrender in Bangladesh; see reports by Sydney Schanberg, New York Times, March 17, 1972, 1-2, and March 23, 1972,12. If, for coding purposes, we treat the formal Pakistani army surrender to India in December 1971 as the end of the civil war, then Pakistan simply becomes an especially bloody case of "state survival"; this does not have any impact on the overall assessment of patterns in the evidence and still reflects badly on core-ethnic-region ethnofederalism, as will be clear below.

${ }^{17}$ The notion of state collapse, therefore, is only one form (but an extremely important form) of "state failure" as defined by Gary King and Langche Zeng, "Improving Forecasts of State Failure," World Politics 53 (July 2001). For them, state failure includes not only state collapse as defined here but also such phenomena as state sponsorship of terrorism, which can certainly be conducted by very strong states that in no way can be said to have collapsed.
} 
very important but smaller-scale conflicts that federations face. As Watts observes: "Federal systems that have persisted do so not because they have eliminated conflict, but because they have managed it." ${ }^{18} \mathrm{We}$ seek to distinguish between those that have managed and those that have not.

\section{The Core-Led Collapse of Ethnofederal States}

Virtually all explanations of the collapse of ethnofederations argue that ethnofederal systems reinforce minority ethnocentric demands and give minority politicians greater resources to push for their eventual realization. Nevertheless, one of the least disputed conclusions in the literature on secessionism is that separatist movements rarely actually succeed of their own accord. For one thing, governments are rarely disposed to part with territory voluntarily and are usually in a strong position to suppress such revolts; for another, the international community also tends to reinforce the status quo. ${ }^{19}$ In order to understand the sources of ethnofederal state collapse, it would therefore seem prudent to focus not only on sources of separatism but also on factors that make ethnofederal regimes more or less able to overcome serious secessionist threats when they do arise. If the factors influencing regime capacity are also found to play a role in provoking or amplifying separatism in the first place, then we will be in possession of an even more powerful theory.

The present article focuses on one particular institutional feature that can greatly weaken an ethnofederal regime's capacity to cope with separatism while at the same time promoting separatism. This factor is not always present among ethnofederal systems. It is the existence of a single, demographically dominant core ethnic region. Core ethnic regions can bring down their "own" ethnofederal states, often unwittingly, for the following three reasons.

\section{How Core Ethnic Regions Promote Ethnofederal STATE COLlaPSE}

\section{DUAL POWER}

Theorists of revolution have long noted that successful revolutions are almost always accompanied by a situation of dual power (or multiple sovereignty), in which a rival source of authority comes to compete

${ }^{18}$ Watts (fn. 6).

${ }^{19}$ Horowitz (fn. 6); Hechter (fn. 6), 83. 
with the state for control over state territory. ${ }^{20}$ The presence of a single federal territorial-administrative structure that contains far more citizens than other regions, in other words a core ethnic region, is almost ready-made for a dual-power situation, posing an inherent challenge to the union state. To see how this is the case, it is helpful to start with a paraphrase of four conditions that Charles Tilly argues are associated with revolutions:

- the appearance of contenders with rival claims to control of the government

- a "commitment to those claims by a significant segment of the subject population"

-the forging of coalitions between incumbent government members and the contenders

- the incapacity (or unwillingness) of government agents to suppress the contenders $^{21}$

Addressing each of these conditions in turn, we can see, first, that core ethnic regions are in fact institutional networks of people and resources that can potentially organize a rival claim to sovereignty and are of sufficient scope to make any such challenge meaningful. Furthermore, leaders of core-region institutions are likely to have interests regarding resource distribution that differ from those of central state leaders, with the former being bound more tightly to narrow coregroup interests and the latter having a greater interest in concessions to minority regions that might be necessary to win the consent of these minority regions to stay in the union. Core-region leaders also tend to have electoral incentives to highlight these differences and to challenge central authorities on these matters.

Turning to Tilly's second condition, core ethnic regions are also well positioned to win the backing of a significant segment of the union's population in any struggle with the union state. Indeed, because of the nature of federalism, the core region's government is already recognized as representative of the will of its own constituents, who by the above definition of "core ethnic region" constitute a large share of the state's citizens. This makes it feasible to argue that under certain circumstances this "core" representative institution is actually a truer represen-

\footnotetext{
${ }^{20}$ Crane Brinton, The Anatomy of Revolution (New York: Vintage Books, 1965); Charles Tilly, "Revolutions and Collective Violence," in Fred I. Greenstein and Nelson W. Polsby, eds., Handbook of Political Science, vol. 3 (Reading, Mass.: Addison-Wesley, 1975).

${ }^{21}$ Tilly (fn. 20), 521. Of course, dual-power situations can occur within isolated regions of a country, as when the Chechen leadership challenges Moscow's authority locally. What makes a core ethnic region particularly important is that it spawns challenges that threaten the authority of the central government across the country's whole territory.
} 
tative of its people than is the central government, whose claim can thereby be delegitimated. Especially when the core ethnic region represents an ethnic group that has historically been politically dominant in the region, as is often the case, it is not hard for core-region politicians to justify a claim to be the leading voice of the entire federation.

Third, the resources and claims to loyalty that core regions possess can also be used to co-opt members of the central government in the course of any conflict between the core region and the central government. This potential, too, makes a core ethnic region a formidable rival to any federal government whose country contains one.

Fourth and finally, central leaders will likely find it very costly to suppress core ethnic regions that do all of the above and directly challenge central authority. Such a situation makes a federal crackdown less likely to succeed. If the union faces separatist pressures from minority regions, it may also be unable to make the kind of concessions demanded by the core region in return for peacefully relinquishing its challenge to central sovereignty.

Ironically, therefore, even when a core ethnic region intends to save the larger union or to improve its own group's position in it, it threatens to undermine the union. This is because its very existence as a core ethnic region creates the potential for the rise of the type of dual-power situation that historically has proved as deadly to multiethnic states as have the processes of ethnic minority nationalist "outbidding" or separatist "bandwagoning" that are often considered the main danger. Crane Brinton writes of a typical rival power center in a dualsovereignty situation:

$[N]$ ot all of its leaders and followers are from the beginning consciously aiming to supplant the legal government. Very often they think of themselves as merely supplementing it, perhaps also as preserving it in a revolutionary course. Yet a rival government they are, and no mere critics or opponents. At a given revolutionary crisis they step naturally and easily into the place of the defeated government. ${ }^{22}$

\section{SECURITY THREATS}

The existence of a single core ethnic region can also be particularly threatening to minority republics, thereby sowing distrust, undermining cooperative arrangements, and potentially provoking conflict. For one thing, the existence of a core region - the institutions of which may cover a large share of the country's territory and resources-is often

${ }^{22}$ Brinton (fn. 20), 133-34. 
seen as strengthening the bargaining position of the core group (a disproportionately populous group potentially or actually constituting a core ethnic region) in negotiations over ethnofederal arrangements: other regions fear that they will permanently get the short end of the federal stick in resource allocations and federal policy-making more generally. ${ }^{23}$ That the core ethnic region may represent an alternative institutional base for core-ethnic-group members disaffected from the central government creates additional possibilities for core-group "defection" from loyalty to the federal government. The result can pose a potential threat to the very existence of the central government and can foster fears in other regions that the central government, in an effort to avert defection of this most critical group, will be more responsive to core-region demands than to those of other regions. A central government will typically try to reassure minority regions that it has their best interests at heart, of course. But the fact remains that the core ethnic region may possess the capacity to force the central government to renege, either by refusing to implement concessions to minority regions that come at a core group's expense or by forcing the central government to take more aggressive actions against minorities. Central efforts at trust building and bargaining, widely held to be key to the capacity of federal systems to hold together and avoid conflict, are thus likely to be seen as less credible when a core ethnic region is present.

\section{COMMUNITY IMAGINING}

The existence of a core ethnic region renders more conceivable the idea that the core ethnic group can exist apart politically from other sections of the country designated for other minorities. Political entrepreneurs can point to a premade, "embryonic" core nation, complete with borders and state institutions, that can be said not to need the minority regions or that can be said even to be better off without them. ${ }^{24}$ As such, its institutions can serve as focal points around which to promote powerful new identifications. ${ }^{25}$ The presence of a core institutional structure also lowers the expected costs involved in creating a new core-group state separate from the other ethnic regions.

\footnotetext{
${ }^{23}$ Others, from John Stuart Mill in Representative Government to Jonathan Lemco, stress a closely related form of tension in federations more generally, noting that it often comes to a head when deciding how many seats to allocate to each region in federal parliaments; see Lemco, Political Stability in Federal Government (New York: Praeger, 1991).

${ }^{24}$ See sources in fn. 2. On community imagining, see Benedict Anderson, Imagined Communities (New York: Verso, 1991).

${ }^{25}$ Henry E. Hale, "Explaining Ethnicity," Comparative Political Studies 37 (May 2004); Thomas C. Schelling, The Strategy of Conflict (Cambridge: Harvard University Press, 1980).
} 


\section{How the Absence of a Core ETHNic Region Promotes ETHNOFEDERAL STATE SURVIVAL}

There are two ways in which a core ethnic region can be absent. The first is important and needs little elaboration. If no ethnic region is large enough to be considered dominant by the criteria given earlier, no region is likely by itself to become a source of dual power or to pose extraordinary difficulties for the central government in making credible commitments to the security of other ethnic regions. This is so even when all such ethnic regions represent "fully imagined" communities. This, then, addresses two of the three key union-destabilizing dynamics just discussed and renders the third less threatening.

A second way in which a core ethnic region can be absent involves a situation where a core ethnic group is divided up into a number of regions with or without official ethnic status. This recalls Donald Horowitz's well-known argument that subdividing regions generally tends to facilitate ethnofederal stability. ${ }^{26}$ When a core ethnic region is carved up, the core group faces high hurdles to collective action that is aimed at realizing core-group goals within the union state and that can threaten union collapse for the reasons outlined above. Collective action theory suggests that problems of coordination among the divided core-group regions will be more severe to the extent that the core group is parceled out into greater numbers of regions, to the extent that these regions interact with each other less intensely and frequently, to the extent that individual regions lack an effective capacity to punish other regions that decide not to cooperate, and to the extent that these regions lack agreement on the exact point at which joint action is warranted and expected. ${ }^{27}$ This has the following implications.

\section{DUAL POWER}

The concept of dual power directly assumes collective action on the part of the challenging authority. Certainly, a charismatic core-nationalist leader may organize a power structure to rival that of the official government solely on the basis of ideology or his own personal authority. But this task is made that much easier to the extent that there is a

\footnotetext{
${ }^{26}$ Horowitz (fn. 6).

${ }^{27}$ Mancur Olson, The Logic of Collective Action (Cambridge: Harvard University Press, 1965); Russell Hardin, Collective Action (Baltimore: Johns Hopkins University Press, 1982), 211-13; Barry R. Weingast, "The Political Foundations of Democracy and the Rule of Law," American Political Science Review 91 (June 1997); Steven L. Solnick, "Is the Center Too Weak or Too Strong in the Russian Federation?" in Valerie Sperling, ed., Building the Russian State (Boulder, Colo.: Westview, 2000), 138-40; John M. Veitch, "Repudiations and Confiscations by the Medieval State," Journal of Economic History 46 (March 1986); Douglass C. North and Barry R. Weingast, "Constitutions and Commitment," Journal of Economic History 49 (December 1989).
} 
ready-made set of representative institutions and integrated resources that already claim to be the democratic voice of the core group in the state. Creating numerous smaller institutional structures representing different segments of the core group makes dual power much less likely to arise, since it produces many rival claims to the same voice and opens up many possibilities for central governments to divide and conquer. This point is supported by Horowitz's important insight that dividing up massive federal regions can refocus much political conflict away from competition for control of the central state and toward competition for control of the smaller federal units. ${ }^{28}$

\section{SECURITY THREATS}

The division of the core group into more than one territorial unit can also reduce the perception of threat that minority regions feel coming from the core group. Nationalist rhetoric and signs of chauvinistic intent are more threatening when they are articulated by core-region leaders who look to be capable of one day carrying out related actions either through their own or through federal institutions. Furthermore, such threatening symbolics are more likely to come from a core region's leadership than from a central government because the central government has more of a direct interest in avoiding alienating minority regions, since its future depends more immediately upon keeping them in the union. The presence of multiple, smaller core-group regions can also help make cooperative agreements reached with ethnic minority regions sturdier and more attractive. In this kind of union, the central government can play one core-group region off the other in order to extract concessions from the core group as a whole and thereby co-opt or appease minority regions. Likewise, any deals struck are likely to be more credible since none of the many core-group regions (at whose expense concessions might be made) is likely alone to be capable of reneging on commitments made.

\section{COMMUNITY IMAGINING}

Finally, breaking up core groups into multiple regions without a broader core federal territorial unit makes it more costly for political entrepreneurs to advance the idea of a core-group state independent of ethnic minority regions. Because such political actors are less likely to have institutional resources that stretch (or are fully mobile) across the span of "core-group territory," it is more difficult to mobilize people

${ }^{28}$ Horowitz (fn. 6). 
around a specific identification with the territory defined by these particular borders. Any attempt to build an independent core-group country would likewise face enormous costs of institution building that weaves together many separate regional administrative structures. Identity, as a result, will instead tend to be politicized more intensely at other levels-not just around the union as a whole but also at the level of subgroups, as Horowitz argues, as well as around individual coregroup regions. ${ }^{29}$

\section{Global Patterns of Ethnofederal State Survival AND COLLAPSE}

If this logic is correct, it should provide leverage in explaining patterns of collapse and survival among ethnofederal states worldwide. Specifically, it is argued that ethnofederal countries with a core ethnic region (that is, an ethnically designated region that has clear numerical superiority in terms of population) will be more likely to collapse than those ethnofederal states without such a core ethnic region. This study has thus compiled information on all ethnofederal states, as defined earlier, that have existed worldwide since the end of World War II. It uses as a starting point and then updates information provided by Elazar's comprehensive list of federal polities and Gurr's cross-national study of "minorities at risk." ${ }^{30}$ After the universe of ethnofederal states was identified, these cases were categorized according to whether they collapsed or have survived according to the definition given above. A breakdown is given in Figure 1.

As is true with most large-scale social science classification schemes, there are inevitably some cases that lie in a gray area between categories. In this instance, some countries have been characterized as ethnofederal by some experts but not by others, either in print or in consultation with the author. Most of the disagreement revolves around whether certain federations truly have an ethnic foundation. For example, Elazar writes that "the basis for Mexican federalism may be

\footnotetext{
${ }^{29}$ Horowitz (fn. 6); Hale (fn. 25).

${ }^{30}$ Daniel J. Elazar, Federal Systems of the World (Essex: Longman, 1991); Gurr (fn. 5). In this compilation process, I consulted a great deal of published material and also regional experts where cases remained unclear. If any cases have been omitted from this study, it can be concluded that such cases are likely quite obscure, not cited by major works on ethnofederalism and not widely discussed by area experts. The only category of state systematically omitted from the study is that of island microstates with federal state structures, on which reliable data on the relationship between federal structure and ethnic composition have proved extremely elusive. Island ministates listed as federations by Elazar include Antigua and Barbuda, the Comoros, the Netherlands Antilles, St. Kitts \& Nevis, the Solomon Islands, and Vanuatu.
} 


\begin{tabular}{|c|c|c|c|c|}
\hline $\begin{array}{l}\text { State Survival } \\
\text { Peaceful } \\
\text { Ethnofederation }\end{array}$ & $\begin{array}{c}\text { State Survival } \\
\text { Ethnofederalism } \\
\text { Ended }\end{array}$ & $\begin{array}{l}\text { State Survival } \\
\text { Limited "Ethnic" } \\
\text { Violence or } \\
\text { Isolated } \\
\text { Seccession }\end{array}$ & $\begin{array}{c}\text { State Collapse } \\
\text { Breakup }\end{array}$ & $\begin{array}{c}\text { State Collapse } \\
\text { Large-Scale } \\
\text { Civil War }\end{array}$ \\
\hline $\begin{array}{l}\text { Belgium 1993- } \\
\text { Tanzania 1992, } \\
\text { 1995- } \\
\text { Bosnia 1995- }\end{array}$ & $\begin{array}{l}\text { Indonesia 1949-50 } \\
\text { Pakistan 1985-99 } \\
\text { Cameroon 1961-72 }\end{array}$ & $\begin{array}{l}\text { Serbia \& } \\
\quad \text { Montenegro } \\
\text { 1992, 1999- }\end{array}$ & $\begin{array}{l}\text { Czechoslovaka } \\
1990-92 \\
\text { Mali Federation } \\
1960 \\
\text { USSR 1990-91 } \\
\text { Senegambia } \\
\text { 1982-89 }\end{array}$ & $\begin{array}{l}\text { Nigerian 1st } \\
\text { Republic } \\
\text { 1960-66 } \\
\text { Pakistan 1970-71 } \\
\text { Yugoslavia } \\
\text { 1990-91 }\end{array}$ \\
\hline $\begin{array}{l}\text { Canada 1867- } \\
\text { Switzerland 1848- } \\
\text { Gbana 1992- } \\
\text { South Africa 1994- }\end{array}$ & $\begin{array}{l}\text { Nigerian 2nd, } \\
\text { 3rd Republics } \\
\\
\text { Papua New } \\
\text { Guinea 1977-90 }\end{array}$ & \begin{tabular}{|l|} 
Ethiopia 1995- \\
India 1956- \\
Nigerian 4th \\
Republic 1999- \\
Russian Federation \\
1991- \\
Spain 1979- \\
\\
Malaysia 1957- \\
Mexico 1917-
\end{tabular} & & \\
\hline
\end{tabular}

\section{Figure 1}

\section{Patterns of Survival and Collapse among Ethnofederal States ${ }^{a}$}

2Country names in italics refer to "borderline ethnofederations," as discussed in the article.

found in some of the basic divisions within Mexican society, in particular the different Indian tribes inhabiting the different states and the mixture of languages which have resulted from that fact." ${ }^{31}$ One specialist on Mexico and ethnicity consulted by the author voiced virtually the opposite conclusion in very strong terms, however, calling Elazar's interpretation "a neo-Nativist revisionism completely contrary to historical fact" and averring that Mexican federalism has had no significant ethnic content and thus should not be coded as ethnofederal. Mexico is thus considered here a "borderline" case, one that could be categorized either as ethnofederal or not ethnofederal, depending on the expert one consults.

An even more difficult borderline case is Cameroon. Many scholars regard the two regions in its 1961-72 federation as having no essential

\footnotetext{
${ }^{31}$ Elazar (fn. 30), 160.
} 
ethnic distinction; one province was simply the one ruled by the French (French Cameroon) and the other the one ruled by the British (British Southern Cameroon) during the colonial period. In this light, Cameroon appears to be like Libya in 1951-63, a federation with component regions based on different experiences under colonial rule, not ethnicity; this would exclude it from the present study. What differentiates Cameroon's federation from Libya's, however, is an overarching language difference between the two federal regions, often called Anglophone Cameroon and Francophone Cameroon. While some would argue that such colonially imposed linguistic differences should not be counted as ethnic, others write that "distinct Anglophone and Francophone identities and nationalisms" had emerged under colonial rule. ${ }^{32}$ One does not find the latter kind of statements written about Libya's three federal regions, in each of which Arabic was the dominant language. Thus while Libya 1951-63 was clearly not ethnofederal, Cameroon 1962-73 might be counted either way, depending on which expert one talks to.

What to do when country experts differ? While one approach would be to take a position on these disagreements, disputes such as these are not easily resolved by outside scholars, since they involve nuanced interpretations of the historical record ${ }^{33}$ This problem would be damaging to the present analysis if not for one fact: it makes no difference to this study's findings whether one codes the borderline countries as "ethnofederal" or "not ethnofederal" because none of them provides a single example of a state without a core ethnic region that collapsed, as is discussed below. Since this paper does not aspire to a definitive typology of federations but merely seeks to evaluate the theoretical claims stated above, the following solution is adopted: "Borderline ethnofederations" are counted as ethnofederations in the discussion below but are noted in italics in the summary of findings (Figure 1). This way, readers can see for themselves the implications of leaving them out of the analysis. Cases like Libya 1951-63, whose status as a nonethnic federation is generally undisputed, are of course excluded from the study.

To facilitate analysis, after identifying countries that are at least borderline ethnofederations and classifying them as instances of "collapse"

\footnotetext{
${ }^{32}$ On Cameroon, see Nicodemus Fru Awasom, "Negotiating Federalism: How Ready were Cameroonian Leaders before the February 1961 United Nations Plebiscites?" Canadian Journal of African Studies 36, no. 3 (2002); Emmanuel Chiabi, The Making of Modern Cameroon, vol. 1 (Lanham, Md.: University Press of America, 1997); and Paul Nchoji Nkwi and Francis B. Nyamnjoh, eds., Regional Balance and National Integration in Cameroon (Leiden, The Netherlands: African Studies Centre, 1995).

${ }^{33}$ On the dangers of comparative scholars drawing on secondary interpretations of history, see Ian S. Lustick, "History, Historiography, and Political Science," American Political Science Revierw 90 (September 1996).
} 
or "survival," it is helpful to further break down the category of "collapse" into its two chief components, state breakup and large-scale civil war. Naturally, countries do not fall neatly and identically into these two categories. Yugoslavia, for example, both broke apart and descended into large-scale civil war. A more nuanced breakdown of these categories, however, would only distract from the central point of this analysis and is thus left for future work.

The category of "state survival" is analogously subdivided so as to make clear that "survival" encompasses a variety of outcomes. Survival thus includes not only the ideal "peaceful ethnofederation" but also instances where ethnofederal systems have survived while continuing to face limited ethnic violence or an isolated secession (as with today's Russia), as well as those where a state abandons its ethnofederal institutions in the process of surviving as a state (as with the United States of Indonesia in 1950). Naturally, there are differences of degree within each category. Furthermore, Pakistan 1985-99 represents a case that both liquidated its ethnofederal institutions and experienced limited ethnic violence prior to that time. Since, however, these nuances make no difference for the central conclusions of this study, they are left for treatment in other work.

\section{THE Findings}

The overall findings, summarized in Figure 1, are striking. Initially, we see overwhelmingly that ethnofederal states lacking a core ethnic region are very resistant to collapse--in fact, this investigation did not reveal a single case of collapse among thirteen such states. Conversely, all cases of ethnofederal state collapse bave taken place in systems that featured a core etbnic region. Out of a total of fourteen core-ethnic-region cases, seven have collapsed, three involving large-scale civil war.

While this general pattern provides striking evidence for the propositions advanced above, a closer look at the kinds of cases populating the categories in Figure 1 adds confidence to this conclusion. For one thing, all of the long-lived ethnofederations are in the category without core ethnic regions. Some of these, such as India and Malaysia, have endured for many decades while Switzerland and Canada have survived for well over a century. Although all of these countries have experienced significant ethnic tension, it is remarkable that they have nevertheless possessed the institutional wherewithal to cope and live on. If one turns to the set of ethnofederations possessing core ethnic regions, not only have half of them collapsed but there is also not a single longlived ethnofederation among them. Indonesia abandoned its ethno- 
federal system after less than a year in 1950. Pakistan's first genuine attempt also lasted for less than a year, imploding in $1971 .^{34}$ Pakistan's second attempt endured a bit longer, but still only about fifteen years. Similarly, Cameroon's core-ethnic-region ethnofederalism was scrapped after just about eleven years. The other four cases of survival with a core ethnic region (Belgium, Bosnia, Tanzania, and Serbia and Montenegro) were all created only in the 1990s. Not only have these cases been untested by time, but, with the possible exception of Belgium, they are regarded by experts as being among the world's most fragile union states. Bosnia, for example, has been propped up by NATO peacekeeping troops since its inception. Similarly, Serbia and Montenegro, forged out of what was left of Yugoslavia after its civil wars of the early 1990s, has one of its regions (Kosovo) occupied by NATO because of ethnically related conflict and another (Montenegro) increasingly flirting with the idea of complete independence. Overall, not one country has survived even close to twenty years as an ethnofederation with a core ethnic region, whereas six ethnofederations without core regions (nearly half of all instances) have far surpassed this mark and none have collapsed.

It is also important to note that patterns of success and failure cannot be reduced simply to geographic or temporal factors. Remarkably, surviving ethnofederal states are found in all of the geographical contexts where ethnofederal state collapse has occurred. Thus while three postcommunist ethnofederations with core ethnic regions broke apart (the USSR, Yugoslavia, and Czechoslovakia), the Russian Federation without one has survived. While Nigeria's First Republic, the short-lived Mali Federation of 1960, and Senegambia each collapsed with core ethnic regions, one can point to relative success stories in Africa in Nigeria's successor republics, as well as in Ethiopia, South Africa, and Ghana. Similarly, whereas Pakistan 1970-71 represents a South Asian "failure" with a core ethnic region, India is a South Asian "success" without a core ethnic region. Moreover, both survivals and collapses can be identified throughout the time since World War II; it is not the case that failures are all clustered in one period and successes in another. All this strongly suggests that the observed pattern is not simply a reflection of omitted cultural, temporal, or other contextual variables.

If we move from analysis of these broad patterns to an examination of just how the various ethnofederations collapsed and survived, we do

\footnotetext{
${ }^{34}$ Some have classified Pakistan as having been an (ethno-) federation since 1956, when a nominally federal constitution was adopted. It is not coded as being ethnofederal here until 1970 , since elections were not held for the federal and provincial parliaments between 1956 and 1970. See Craig Baxter, "Pakistan Votes-1970," Asian Survey 11 (March 1971). This coding decision, however, has no impact on this article's overall findings.
} 
in fact find core ethnic regions centrally involved in the collapses, producing dangerous situations of dual power, generating security fears on the part of ethnic minority regions, and/or fostering distinct coreregion identifications that could be mobilized against union structures. Let us first turn to the most tragic cases, those involving large-scale civil war. In Nigeria, a gigantic Northern Region dominated by the Hausa tribe and containing some 55 percent of the country's population was perceived as overly influential by the minority Igbo tribe's region, whose leaders first attempted a coup and then declared independence, launching a civil war that lasted three years and caused hundreds of thousands of deaths. ${ }^{35}$ Similarly, Pakistan's 1970-71 ethnofederation consisted of the predominantly Bengali-speaking core Eastern province separated geographically-with India in betweenfrom four western ethnic provinces. ${ }^{36}$ Trouble started after the December 1970 general election, in which an exclusively Eastern-based party surprisingly won an outright majority of seats in the country's parliament. After the main Western-based party refused to accept the outcome and negotiations failed to reach a compromise, the country's president, General Agha Muhammad Yahya Khan, refused to honor the Eastern party's right to form a government. This spawned fullfledged civil war that eventually produced Indian intervention and the secession of the Eastern province, which became Bangladesh. ${ }^{37}$ Finally, Serbian leaders sounded the death knell of Yugoslavia when they refused to turn the chair of the ethnofederation's rotating collective presidency over to the Croatian representative, helping to set off a separatist cascade involving key minority regions. When Serbia then took the lead in employing military might to restore the union, the result was a major civil war that produced tens of thousands of casualties as well as the breakup of the country when the operation failed. ${ }^{38}$

Turning now to instances of more peaceful state breakup, one finds that in the USSR, with its fifteen federal regions, the majority Russian Republic had systematically challenged Soviet authority on its territory,

\footnotetext{
${ }^{35}$ Martin Dent, "Ethnicity and Territorial Politics in Nigeria," in Smith (fn. 5). See also the case study on Nigeria below.

${ }^{36}$ The four western provinces were created from a united Western province just prior to the 1970 elections.

${ }^{37}$ Craig Baxter, "Pakistan and Bangladesh," in Frederick L. Shiels, ed., Ethnic Separatism and World Politics (New York: University Press of America, 1984); Baxter, "Constitution Making: The Development of Federalism in Pakistan," Asian Survey 14 (December 1974); Robert LaPorte, Jr., "Pakistan in 1971: The Disintegration of a Nation," Asian Survey 12 (February 1972); Sharif al Mujahid, "Pakistan: First General Elections," Asian Survey 11 (February 1971).

${ }^{39}$ Bunce (fn. 2); Crawford (fn. 2); Rusinow (fn. 15); Susan L. Woodward, Balkan Tragedy: Chaos and Dissolution after the Cold War (Washington, D.C.: Brookings Institution Press, 1995).
} 
destroying key federal state institutions in a struggle for power, as described in more detail below. Moreover, after a hard-liner coup sought to put an end to this but failed, the Russian Republic joined with two other Soviet republics in officially declaring the end of the USSR. ${ }^{39}$ Czechoslovakia's "velvet" breakup involved a number of issues, but one of the most important was a series of economic reforms implemented by the federal government (with Václav Klaus, a Czech, as finance minister) during 1990-92 that cut subsidies to Slovakia and that were understood as primarily benefiting the Czech economy. When Slovakia's government then rejected this and the core Czech Republic (led by Klaus after a 1992 republic election victory) refused to compromise, the republics decided to part ways despite the fact that majorities of both Czechs and Slovaks preferred a continuation of the federation. ${ }^{40}$ The Mali Federation, joining what are now Mali and Senegal upon their gaining independence from France in June 1960, fell apart after just two months when the regions' leaders could not agree on a distribution of power and when the core region, Senegal, worried that the arrangement was not to its economic advantage. ${ }^{41}$ Senegal joined another ethnofederal project in 1981, when it sent troops to Gambia to put down a leftist rebellion that the latter state could not contain and that the former feared could come to threaten Senegal. The result was Senegambia, which came into being in 1982. Fearful of absorption by the larger (core) Senegal, however, Gambia's leaders persistently resisted formalizing integration arrangements and insisted on a rotating presidency, which Senegal rejected. After years of tensions and a lack of progress in institution building and following some local violence, Senegambia dissolved in 1989.42

Figure 1 also makes clear, however, that not all states with core ethnic regions collapse; a crude reading of the figure suggests that the probability of such a state collapsing is about 50 percent. It is thus worth stressing that no claim is made for core ethnic regions being the

\footnotetext{
${ }^{39}$ Virtually all authoritative accounts confirm this role for the Russian Republic. See John B. Dunlop, The Rise of Russia and the Fall of the Soviet Empire (Princeton: Princeton University Press, 1994); Jerry F. Hough, Democratization and Revolution in the USSR (Washington, D.C.: Brookings Institution Press, 1997); Stephen Kotkin, Armageddon Averted (New York: Oxford University Press, 2001); Michael McFaul, Russia's Unfinished Revolution (Ithaca, N.Y.: Cornell University Press, 2001).

${ }^{40}$ Bunce (fn. 2), 87-98; Abby Innes, "The Breakup of Czechoslovakia: The Impact of Party Development on the Separation of the State," East European Politics and Societies 11 (Fall 1997); Leff (fn. 2), 226-27.

${ }^{41}$ Donn M. Kurtz, "Political Integration in Africa: The Mali Federation," Journal of Modern African Studies 8 (1970), 405-24.

${ }^{42}$ On Senegambia, see Tijan M. Sallah, "Economics and Politics in The Gambia," Journal of Modern African Studies 28 (December 1990), 621-48; Robert H. Jackson and Carl G. Rosberg, "Why Africa's Weak States Persist: The Empirical and the Juridical in Statehood," World Politics 35 (October 1982), 12; and The Cambridge Factfinder (http://www.ifes.org/eguide/country/senegal.htm).
} 
sole or sufficient cause of state collapse. Instead, for the reasons elaborated above, core ethnic regions make ethnofederations much more vulnerable to collapse in the face of exogenous shocks, ethnically charged conflicts, and other crises states may face. ${ }^{43}$

While a full treatment will have to await future work by other scholars, Figure 1 helps us begin to identify the kinds of shocks, conflicts, and crises these might be. For one thing, as many have noted, the transition from Communist Party rule was an extremely difficult process, involving the rather sudden and simultaneous needs to establish entirely new political and economic systems in addition to resolving any ethnic tensions that happened to arise. This appears to have been too much for those ethnofederations least equipped to handle such challenges, those with core ethnic regions. Thus the USSR, Yugoslavia, and Czechoslovakia all collapsed. ${ }^{44}$ We cannot blame the transition alone for these collapses, however, since the Russian Federation (lacking a core ethnic region) faced the same pressures yet proved able to survive despite predictions by many highly qualified observers that it would disintegrate as part of the same process that brought down the USSR. ${ }^{45}$ Another historical shock that appears to have been particularly threatening to core-ethnic-region ethnofederations is the acquisition of independence after decolonization. Thus Nigeria's First Republic and the Mali Federation both collapsed, while the only other two cases of "immediately postcolonial ethnofederations" with core ethnic regions, Indonesia in 1949 and Cameroon in 1961, soon wound up eliminating their ethnofederal institutions. In contrast, Malaysia, which emerged from colonial rule as an ethnofederation lacking a core ethnic region, was able to withstand such challenges and survived as an ethnofederation. Patterns in Pakistan 1970-71 and Senegambia reflected other shocks, a provocative and unexpected electoral outcome ${ }^{46}$ in the former and a power struggle and domestic conflict in the latter, as noted above.

The ethnofederal states that have survived as such despite core ethnic regions have arguably had these institutions for too little time to experience such shocks, as discussed above. One should not be too quick

\footnotetext{
${ }^{43}$ Indeed, this study nowhere claims that ethnofederations without a core ethnic region will never collapse in the face of such pressures, just that they are less likely to do so than those with a core ethnic region.

${ }^{4}$ Here see works cited in fn. 2, most notably Bunce and Leff.

${ }^{45}$ For one of many works reporting such predictions, see Daniel Treisman, After the Deluge (Ann Arbor: Universiry of Michigan Press, 1999), 3.

${ }^{46}$ This outcome was widely attributed to a devastating cyclone that hit the Eastern province just three weeks before the voting; when Western-based Pakistani authorities were not perceived to have responded adequately, support for the leading Eastern party surged in the core East. As a result, it won almost every Eastern seat, which was enough to constitute an outright majority in the parliament of Pakistan as a whole. See Baxter (fn. 34).
} 
to assume that the surviving core-ethnic-region ethnofederations will eventually collapse, however. The two that have maintained the greatest levels of peace without foreign military occupation, Belgium and Tanzania, have also established elaborate consociational ethnic powersharing arrangements that supplement their federal institutions, policies that some leading scholars argue tend to facilitate interethnic concord more generally. ${ }^{47}$

Turning now to those thirteen ethnofederations that lack core ethnic regions, Figure 1 illustrates that they have been far from perfect. To be sure, Canada and Switzerland have remained both peaceful and ethnofederal for well over a century despite a major challenge faced by the former in a 1995 referendum on Quebecois independence. But seven of the thirteen have experienced at least some limited violence involving ethnic claims or an isolated but serious secessionist movement. While Mexico since its revolution has faced no threat to its existence as a state, for example, it recently saw the Chiapas rebellion, which it quickly contained. In another case, Singapore seceded from Malaysia in 1965, but the rest of Malaysia did not unravel.

It is interesting to note, however, that in every other instance, ethnic conflict or separatism had been a feature of these countries prior to the adoption of non-core-ethnic-region ethnofederalism. Ethiopian ethnofederalism emerged after a long civil war and even that regime's critics note that it has represented an improvement over that recent past. ${ }^{48}$ Eritrea in fact seceded as a result of this war prior to the establishment of ethnofederal institutions there. Now the country experiences only sporadic and largely contained domestic violence. India's ethnofederal system was adopted mainly as a means to preserve the country in response to preexisting ethnic conflict and most scholars regard it as a relative success. ${ }^{49}$ The Chechen challenge to Russian rule began under the USSR in 1991, when a Soviet general (Dzhokhar Dudaev) effectively staged a coup in Chechnya and declared independence. Nigeria's Second through Fourth Republics, of course, were dealing with the legacy of that country's deadly civil war. Similarly, Spanish ethnofederalism was designed to contain preexisting Basque violence. While their forms of ethnofederalism have not succeeded in eliminating conflict entirely, these states have managed to avoid the fate of countries like Yugoslavia, which experienced breakup and/or intense wars that led to

${ }^{47}$ Most prominently, Lijphart (fn. 5).

${ }^{48} \mathrm{John}$ W. Harbeson, “A Bureaucratic-Authoritarian Regime," Journal of Democracy 9 (October 1998).

${ }^{49}$ Brass (fn. 5), 111. On reasons for India's most serious separatist crisis, see Sumit Ganguly, The Crisis in Kashmir (New York: Cambridge University Press, 1997). 
hundreds of thousands of deaths. Critically, they have often done so while facing the same kinds of problems or shocks that have been implicated in the collapse of ethnofederations that possessed core ethnic regions, as described above. They have also frequently done so for quite a long time, with India's and Malaysia's ethnofederations lasting nearly half a century and Mexico's enduring nearly twice as long.

Not all have survived as ethnofederations, of course. Nigeria's second and third republics, lacking core ethnic regions, were ended by coups d'état, and Papua New Guinea retracted the autonomy granted to one of its provinces. While the Nigerian coups had little to do with ethnofederal pressures, Papua New Guinea's actions came in response to a declaration of independence by Bougainville. These crises, however, were not sufficient to send these countries along the road to state collapse, unlike some core-ethnic-region countries that faced similar problems.

Since this study argues that having many core-group regions instead of a single core ethnic region reduces the likelihood of union collapse, it can be seen as a specification of the general notion that the greater number of federal regions in a federation, the more stable it is. ${ }^{50}$ Thus we observe that no ethnofederation with more than the USSR's fifteen federal units has ever collapsed. The simple numbers argument, however, gives us less explanatory power because fewer than a third of all ethnofederations (only India, Malaysia, Mexico, Nigeria, Papua New Guinea, Russia, Spain, and Switzerland) have in fact contained more than fifteen units. More important, however, reference only to numbers is to lose sight of what we know about how ethnofederal collapse has occurred, which is that core ethnic regions have played a critical role in each case. This will become even more clear in the case studies below. Thus, while on balance the evidence does suggest that a greater number of regions means ethnofederal collapse is less likely, the most important thing is whether one of the regions is a core ethnic region.

Overall, global patterns strongly support the notion that ethnofederations are more likely to collapse when they possess core ethnic regions. To gain even more confidence that the logic of the theory is in fact at work in these patterns, it is helpful to examine at least a couple of cases in greater depth than is possible in the above analysis of global patterns. To maximize empirical leverage, special attention is trained on a particularly methodologically useful set of countries, those that at different times both possessed and lacked core ethnic regions. By demonstrating that the same cultures and peoples experienced different

\footnotetext{
${ }^{50}$ Albert Breton and Anthony Scott, The Design of Federations (Montreal: Institute for Research on Public Policy, 1980); Horowitz (fn. 6); Lemco (fn. 23).
} 
outcomes under these circumstances and did so in ways predicted by the theory, we gain greater assurance that contextual variables are not the only ones at work and that the theory captures a real and important dynamic. We thus turn here to Nigeria and the USSR/Russia.

\section{NIGERIA}

Established upon attaining independence in 1960, Nigeria's First Republic was divided up into three (and later four) provinces, one for the Igbo tribe, one for the Yoruba, and another for the Hausa, whose "Northern" region made up about 55 percent of the population and thus clearly constituted a core ethnic region. ${ }^{51}$ Indeed, this system proved to be prone to collapse in the ways predicted by the theory, an interpretation borne out by both local observers and participants in Nigeria's history at the time. As one local observer wrote, "It was inevitable that such an over-mighty region would overshadow the federal government and provoke fear of domination among the Southerners. ${ }^{\text {} 52}$ Less than a decade after Nigeria gained independence, Igbo attempts to escape the dominance of the Hausa (a coup and then secession) plunged Nigeria into one of the most deadly civil wars in history (Biafra), a civil war that can be considered a case of state collapse that lasted from 1967 to 1970 . As the regime was breaking down, unionists launched a process of breaking these three regions up into a set of smaller regions, a process successfully imposed nationwide after winning the civil war. There were thirty-seven federal regions as of the time of this writing.

Nigerian leaders interpreted these events in the way described in this article, as is clear from the following excerpt from a speech given by Yakubu Gowon, the military head of state who took power during the First Republic's collapse and carved Nigeria's core ethnic region up into six states as part of a plan to divide all three original states:

The main obstacle to future stability in this country is the present structural imbalance ... while the present circumstances regrettably do not allow for consultations through plebiscites, I am satisfied that the creation of new states as the only basis for stability and equality is the overwhelming desire of the vast majority of Nigerians. To ensure justice, these states are being created simultaneously. ${ }^{53}$

\footnotetext{
${ }^{51}$ Dent (fn. 35); Lijphart (fn. 5), 161-64. A fourth state was created in 1963 from the territory of the Yoruba region.

${ }^{52}$ Dent (fn. 35), 131.

${ }^{53}$ Ugbana Okpu, "Ethnic Minorities and Federal Character," in P. P. Ekeh and E. E. Osaghae, eds., Federal Character and Federalism in Nigeria (Ibadan, Nigeria: Heinemann Educational Books, 1989), 357.
} 
Likewise, the Irkefe Panel, which was set up by Gowon's successor (and overthrower) and which formed the basis for a second wave of regional divisions in 1976, concluded that

1. The political stability of Nigeria could not be guaranteed unless new states were created.

2. More states would strengthen the principles of federalism and produce a balanced and stable federation.

3. The economic and political result to be gained from the exercise will, in fact, encourage unity... .

7. The creation of more states will go a long way in assuaging the fears of minorities. $^{54}$

Most observers treat these Nigerian reforms as successes. Even if they did not eliminate all conflict, they ended the situation in which a core Northern region "overshadowed" the federal government and generated the most acute minority fears for their security and welfare. Importantly, Horowitz concurs by detailing how dividing up the Hausa region also diverted the most active political entrepreneurship from identity-based battles at the federal level to more local disputes based on accentuating more local identifications. ${ }^{55}$ Overall, breaking up the core ethnic region reduced the fears of ethnic minorities, made both majority and minority groups more manageable for the central government, and lessened incentives for the promotion of identification with the core region. While post-Biafra Nigeria has certainly had its share of problems, it has not experienced repetition of the ghastly form of state collapse that it suffered in the late $1960 \mathrm{~s}^{56}$

\section{RUSSIA AND THE USSR ${ }^{57}$}

The USSR contained fifteen constituent "union republics" representing different ethnic groups, with the gigantic Russian Republic being a core ethnic region. The core region's first elected leader, Boris Yeltsin, railed against Soviet policies that had transferred resources from Russia to minority republics, including the sale of Russian oil and gas at far below world prices. In June 1990 the Russian Republic's parliament shook the

${ }^{54}$ Ibid., 356-58.

${ }^{55}$ Horowitz (fn. 6), 612 .

${ }^{56}$ Horowitz (fn. 6), 602-13; Elazar (fn. 30), 186; Robert J. Mundt and Oladimeji Aborisade, "Politics of Nigeria," in Gabriel Almond et al., eds., Comparative Politics Today, 7th ed. (New York: Longman, 2000); Rotimi T. Suberu, Etbnic Minority Conficts and Governance in Nigeria (Ibadan, Nigeria: Spectrum Books, 1996); Hechter (fn. 6), 142.

For more on how this article's logic explains developments in the USSR and Russia, see Henry E. Hale, "Designing Ethnofederalism for Divided Societies: Why Russia Survives Where the USSR Fell," Perspectives on Politics (forthcoming). 
Soviet establishment by declaring "sovereignty," asserting the primacy of its law over that of the USSR, and claiming Soviet property on its territory as its own. In a struggle for control over financial flows, the Russian Republic then effectively liquidated the Soviet state banking system by telling local branch managers that they would be recognized as owners of their branches if they only registered them with a new Russian Central Bank. ${ }^{58}$ In all this, Yeltsin was popularizing an identification with a territorial Russian Republic that was distinct from the traditional Russian identification with its "empire." 59

All of this greatly imperiled the union. The dual-power situation prompted a Soviet hard-liner coup, but Yeltsin defeated it thanks largely to the institutional resources of his gargantuan union republic and his legitimacy as the elected leader of over half of the Soviet population. ${ }^{60}$ In victory, the leadership of the Russian Republic began taking over central Soviet institutions and even voiced territorial claims on certain minority union republics that might try to secede. These moves confirmed minority nationalist fears. Ukraine's leader, preparing for a referendum on independence, now wondered aloud whether Russiandominated union institutions could really "defend the interests of other republics." ${ }^{61}$ Once Ukraine voted overwhelmingly for independence in December 1991, Yeltsin joined with it and Belarus to sign a treaty dissolving the USSR and creating a new Commonwealth of Independent States (CIS), which it hoped would salvage a union relationship with Ukraine. Ukraine, whose leaders and people did not trust Yeltsin's Russia, ensured that the CIS became merely a means to a "civilized divorce." The Russian Republic became the independent Russian Federation.

While the Russian Federation remained primarily identified with ethnic Russians, who constituted about 85 percent of its population, it resembled the USSR in that it itself contained a large number of ethnically distinct federal regions (thirty-one for most of the 1990 s and early 2000s). These minority-designated territories covered 53 percent of the country's landmass. As noted above, many predicted that the Russian Federation would continue the Soviet pattern of dissolution. Russia was critically different from the USSR, however, in that it lacked a core eth-

\footnotetext{
${ }^{58}$ Juliet Johnson, $A$ Fistful of Rubles (Ithaca, N.Y.: Cornell University Press, 2000).

${ }^{59}$ John Dunlop, "Russia: Confronting a Loss of Empire," in Ian Bremmer and Ray Taras, eds., $\mathrm{Na}$ tions and Politics in the Soviet Successor States (New York: Cambridge University Press, 1993), 52; Roman Szporluk, "The National Question," in Timothy J. Colton and Robert Legvold, eds., After the Soviet Union (New York: W. W. Norton, 1992); Astrid Tuminez, Russian Nationalism since 1856 (New York: Rowman and Littlefield, 2000).

${ }^{60}$ Hale (fn. 57).

${ }^{61}$ Roman Solchanyk, "Russia, Ukraine and the Imperial Legacy," Post-Soviet Affairs 9 (OctoberDecember 1993), 350-53.
} 
nic region. Instead, the Russian population outside of the minoritydesignated regions was divided into fifty-seven other territories (here simply called oblasts, although some have other titles).

What is remarkable is that oblast leaders could be found throughout the 1990s voicing grievances against the Russian Federation that were strikingly similar to the complaints that the leadership of the Russian Republic had once leveled against the Soviet central government. Various leaders at various times thus contradicted or ignored federal law, called for impeaching the Russian president, and even, in a few cases, declared sovereignty. ${ }^{62}$

Critically, leading specialists on the Russian Federation have traced its survival in spite of these pressures to federal leadership strategies that exploited the oblasts' lack of any single credible set of alternative institutions around which they could easily rally to advance common interests. Federal leaders, especially while Yeltsin was president (1991-99), thus made great use of strategically placed transfers to buy off or punish potentially troublemaking regions and to subvert those few attempts at joint action that aimed to weaken central authority. Key mechanisms included selective transfers along with a series of "bilateral treaties" between regions and the federal government. ${ }^{63}$ This institutional division of Russians has been so important in identity terms that extensive research has not revealed a single instance of a political entrepreneur envisioning independence for a "Russia" that would coincide with "united oblast" borders, minus the ethnic minority regions. The Russian Federation thus weathered numerous crises even beyond the initial postcommunist transition, including an economic near collapse in 1998. Even a sustained separatist revolt in Chechnya has not spread and has never posed an imminent threat of Russian ethnofederal collapse. ${ }^{64}$ Moreover, once Yeltsin had weathered the biggest shocks to the ethnofederal system, his successor, Vladimir Putin, proved able to implement a series of relatively successful federal reforms designed to buttress state unity and reduce the potential for separatism. ${ }^{65}$ Soviet leader Mikhail Gorbachev after 1990 simply did not have available the strategies that Yeltsin and later Putin used to help preserve the Russian Fed-

\footnotetext{
${ }^{62}$ Yoshiko Herrera, "Imagined Economies" (Paper presented at the annual meeting of APSA, August-September 2000); Solnick (fn. 27); Kathryn Stoner-Weiss, "Central Weakness and Provincial Autonomy," Past-Soviet Affairs 15 (January-March 1999); RFE/RL Newsline 2, no. 125, pt. 1, July 1, 1998.

${ }^{63}$ See Solnick (fn. 27); Stoner-Weiss (fn. 62); Treisman (fn. 45).

${ }^{64}$ Matthew Evangelista, The Chechen Wars (Washington, D.C.: Brookings, 2002).

${ }^{65}$ See Peter Reddaway and Robert W. Orttung, eds., The Dynamics of Russian Politics: Putin's Reform of Federal-Regional Relations (Lanham, Md.: Rowman and Littlefield, 2003).
} 
eration, both because his powers had been stripped away through his struggle with the Russian Republic and because he could not manipulate divisions within the Russian community due to its institutional unity in a core ethnic region.

\section{CONCLUSION}

While most works on ethnofederalism and state collapse have focused on the impact of these institutions on ethnic minority separatism, this institutionalist study has argued that dealing with core ethnic groups is even more important in terms of ethnofederalism's impact both on the intensity of minority secessionism and, critically, on the capacity of central governments to deal with such demands. Ethnofederal states are much more likely to avoid the most extreme problems when any dominant ethnic group is institutionally divided or when no group's region clearly dominates. If the dominant group is so divided, it faces a greater number of hurdles to engaging in core-group-oriented collective action. This, in turn, reduces the likelihood that the central government will face a core-group challenge and also gives the central government opportunities to exploit divisions within the core group. Central governments without core ethnic regions, therefore, are freer to pursue strategies of state preservation that combine bargaining, trust building, and/or coercion. Accordingly, a survey of global patterns has found that all instances of ethnofederal state collapse since World War II have occurred in countries with core ethnic regions and that no state without one has experienced such an extreme event, be it state breakup or largescale civil war. Paradoxically, therefore, the institutional disunity of dominant groups promotes the unity of the ethnofederations they dominate.

Of course, this study has also found that core ethnic regions are only part of the story. The cases of Tanzania and Belgium, for example, indicate that complex ethnic power-sharing arrangements might be able to overcome many of the most dangerous patterns associated with core ethnic regions. Conversely, Figure 1 reports that ethnofederalism, even in the absence of a core ethnic region, cannot be expected to eliminate all violence. Since this theory predicts only that states without core ethnic regions are less likely to collapse, we also cannot rule out the collapse of such a state in the future. Accordingly, we should certainly guard against overconfidence in prescribing non-core-ethnic-region ethnofederalism alone as a solution for conflict-ridden societies; and when we do recommend it, we should be sure to combine it with other compatible measures of conflict resolution and prevention. This study 
does strongly suggest, however, that the chances of avoiding the most horrific large-scale violence and the prospects for sustained state unity in divided societies are significantly improved when ethnofederal systems are crafted without core ethnic regions. A properly designed ethnofederal system, therefore, appears to be a viable political option for societies where ethnic identifications are already conflict-hardened and where there is a premium on continued state unity. 